りますが，目前の事柄だけにとらわれないで先を考えて やつて行かねばなりません。各方面を簧く綜合的と考察 したり、樑く研究して居ればこそ,將來の見通しをつけ て，閒違わずに對策もとれることになると思いをす。 化學工業の中で, 有機合成の重要性や將來の發洼につ
いては，世界の情勢から見ても今更緀々申上げるまです ありませんからこの事業の理論や技衍と實際とを連絡す る協會としての本會の役㓶る谷々重大になるわけであり ます。創立十䓢年記念飞當り, 往時を追想し, 今後の活 躍と毄層を切に期待する次第であります。

\title{
有機合成化學協會に就いての思い出
}

會長黑田泰造

有機合成化學協會も早や†年となつた。早いものであ る。私は其以前の事も少しく述べさせて頂きたい。大體 吾國で有機合成化學, 就中染料, 蓜藥の工業化僦て注 意を引いたのは大正 4 年染料，醫藥の輸入困難になつた からで國產が唱えられた。一う東京瓦斯, 東京工業試驗 所あたりでも考壳て居られたが農商務省商工局長岡賽法 學博士が熱心で，岡の農商務省か農商務省の岡かと云わ れた位のうで，氏の御荟て染料唒藥助成法案が成立した のである。それで永く博士の功蹟を稱えて頂きたい。其 時私達の先生高松豊吉博士が中心となつて三池より中井 四郎，大阪瓦斯より三好久太郎兩博士や私等も呼び出さ

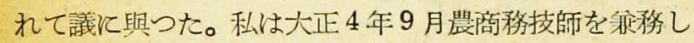
（引續き 10 年間）法案作成，敷地調査等飞參した。10年 閒に 300 萬圓で良から5 と云万樣な話で進み日本染料會 社等 8 分の配當を保登されたのである。三池は铰退し唒

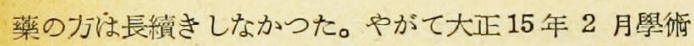
研究會議で染料委員會が出來, 高松博士, 續いて椇島博 土が委員長で私は始から委員であつたが, 昭和 9 年(?) 學衡振興會が發足し其方に移るべきだとて學振が出來た 翌年同會に移つた。學獄振與會では 12 小委員會として 俱島博士に續き長く委員長を勤めたが，此會では普通 3 年位でやめる立前であつた爲め協會の如きものを造つて おくべきだとの事であつたが私は協會の存續が自信がも てず，2 年許りぐずぐずしていたが林茂助博士等の熱心 さに力を得て意々發足する事とし，丁度商工省稻見課長 も熱しれ業界の援助につき話しかけられ，東京會管で發 起人會を開き倣會が成立した。最初の會長は負島博士で
ある。續いて業界と勢力ある石川氏がやられたが氏は無 暗に御忙しいのであるが私は引續き捛願に上りなどした が到々私が御世話する事になつた。敗戰後愈々協會の經 營が苦しかつたが昨年來每月雜誌發行の案が出たが思い 切つて背水の陣を張つて決行した。しかしいくら賀乏で も理事や會員の熱意でかつかつやつて行けるすので別に 刊行物も續々出て居るのである。

有機合成化學は化學の最高の粹であり花であり難しい るのであるが本邦の學者技衡者は充分の能力を持つて居 る。元來本邦は資源乏しいとは云い此方面の原料製品は 高價であり乍ら輕いので運質は多くか」らぬ, 其上此等 製品は頭腦の憉によつて成立しうるものなのだから，此 工業は本邦並に本邦人に對し最も適したものであり, 輝 く希望を持ちうるものである。主たる原料はタール製品 で, 次飞石炭瓦斯, 水性瓦斯, 石油の瓦斯, 天然瓦斯, カーバイド，無機化學製品等である。タール製品は製鐵 業, 瓦斯會社, 肥料等のコークスに附隨するのである が, 此內特に鐵は本邦で原料關係上容易な工業でないが 此鐵が盛大にならねば機珹工業, 造船等も盛になりえぬ。 從つて鐵の盛でない國は貧弱な餘り見込のない國なのて あるが,タールオ面の發達からも鐵を助けて盛としたい と念願する。吾々は安價良質, 多額の鐵, 石炭, 電力を 基碟として各種生產工業を發達せしめ各般の工業が相共 と助け合つて隆盛ならしめて獨立日本の前途を明るくし たい。かくして美しい此島國で孫まです歐米並の生活 水準に昇さればならぬのではないか。

\section{惠まれた誕 生}

監 事青山跡治郎

䀡和 17 年の春比だと思うが，當時商工省に居られた

稻見君に呼ばれて出掛けた时，有機合成化學協會設立の 
事に話が及んだ。も5その時分には，稻見君としては， 腦中に略完成した構想が出來て居た事が，話して居る中 に判然したのだが，兔も角自分としては，その計畫に全 面的に賛成した譯だ。

當時は合成ごムとか合成石油と言つた樣な，有機合成 化學の大企業に屬する樣な問題の研究や中試驗が, 續々 手をつけられたとは言うるのな, 單に戰時目標であつて 研究者の研究意慜を滿足させる程度で, 企業者や經營者 としては，軍の援助でるあれば鬼子角そそうでなければ 自ら進んで企業化し樣とする程の熱意は㱠ど無からた。 又一般的に企業家には有機合成化學工業は「取つきにく い」という感じが强かつた時代であるから，始有機合 成化學協會の樣なるのを創立して, 業界呼びかけ關心 を求める事は, 戰時平時と問わず, 斯業登展に寄與する 所以であろうと考えたのであつた。

この時三つの條件を出した。

第一は基金を十分に用意する事。

第二には有機合成化學工業は範圍が廣いか゚全部を包含す る樣計畫する事。

第三には機關雜誌は純學洋雜誌とならない樣に企畫する 事。
所がこの尤も大切な基金については，稻見君す心配さ れて，己そ牛分位は確賽な预定が出來て居ると言う話。 それと各會社の寄附金（會費ではあるが）の大體の額ま で案が出來て居た。

こんな臎で，此の協會は創立した時は己に詳細は忘れ たが，二十數萬圆の基金が出來て居た。今の金にしたら 4〜5 千萬圓にも相賞するである5。何しろまだ日本が 勢の良い時で，國民も戰勝の歡喜にひたりきつて居た時 代でもあり，今から見れば國民も遥か、有冨であり，文 稻見君の淮供工作が，極めて巧妙確賽飞賽行に移された 事が，との成功の大きな原因であつたと言えよう。自分 も幾つかの協會の創立を見て來たが，この協會位順調に 樂に生れたるのを知らない。

こんなに惠まれた環境に生れ出た本協會も，一度敗戰 と言う冷酷な現實に直面して，總てがご破算になつて以 來は, 外の學協會同樣, 戰後の經營には, 少なから双苦 心を忍んで來られた事は，心から敬意を表したい。

茲に目出度十週年を迎光られ，而も日木も長い占領下 から，漸く獨立國家となつた今日こそ，本協會の本來の 使命を果すべき，好期が到來したと確信するるのであつ て，本協會の監心から祝福する次第である。

\section{戰時中の本邦有機合成企業の歩夕}

\section{副會長北脇市太郎}

眧和 12 年 (1937) 日華事變勃登に伴い物資の自給上 必要な施策が講ぜられたが，有機合成品は需要に應じて 增產を進めるという程度であつた。事變の擴大に伴い航 空機, 各種科學兵器の構成資材並びに繰轱㻜用物資として 有機合成品の重要性が大いに浮び上つてきた。ここにお いて商工省は焦眉の軍需充足はい5まですなく不足資源 の自給，代替品生產と同時飞合成品創造の基礎確立を期 乙有機合成事業法を制定し昭和 16 年 1 月これを施行し た。本事業法で增座と企業化の促進を要望した有機合成 品はつぎの通りである。

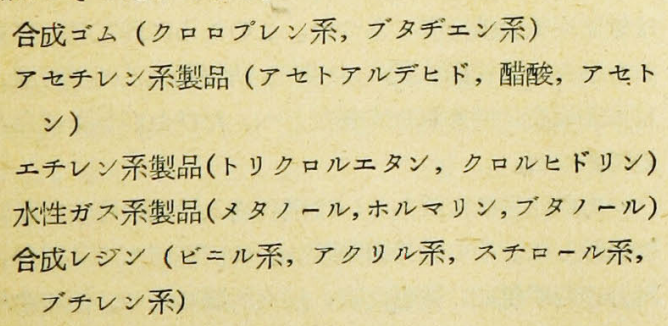

\section{合成繊維}

鞣劑

本事業法の企圖するところは情勢の推移により頓挫し たが，このために有機合成企業の化學工業界に挌ける比 重は相當高まつたのである。

昭和16年5月には有機合成品の生產擴充5 案され日滿支に亘り軍の各部豚が應急的に育成しつつあ つた有機合成關係のあらゆる計畫隹始めて完全に統一さ れた。この計畫の生產目標は當時の國情から見てまるて 雲をつかむよ 5な大規模のもので，その重點は航空燃料 用イソォクタンの原料としてのブタノール，合成ゴムの 增產を期するにあつたが建設資材不足難の見透しなどの ために具現できなかつた。それが机上プランに終つたの は何等精確な科學的調查にもとつかず気力がずてを解 決するとの誤れる信念を以て立案したがためであろう。

太平洋戰爭緒戰の好調に乘じ陸海軍は南方地域に民間 の醱酵ブタノール工場を進出せしめ, 滿洲には滿州電化 